\title{
The impact of Covid-19 lockdown on socio- economic activities in Kaduna State, Nigeria
}

\author{
Abdulkadir Muhammed Yahaya PhD $^{1^{*}}$, Adenike Montiliat ${ }^{2}$, Hajara Salahudeen ${ }^{3}$ \\ Department of Geography, Kaduna State University, Kaduna, Nigeria ${ }^{*}$ \\ Department of Geography, Federal College of Education, Zaria, Kaduna State, Nigeria ${ }^{2,3}$ \\ abdulkadirmuhammed2@gmail.com
}

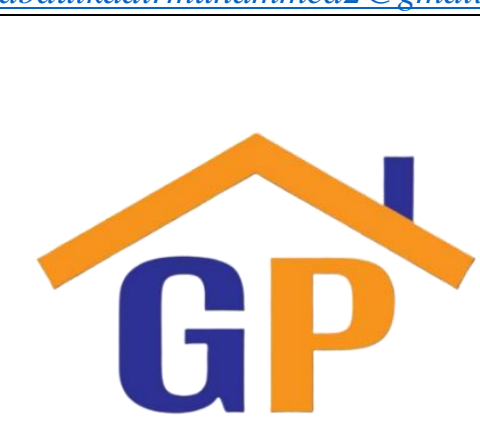

Abstract

Purpose: Coronavirus (Covid-19) pandemic affects social and economic activities all over the world. This study analyses the impact of lockdown caused by the pandemic in Kaduna State, Nigeria, so that the public can appreciate it and take adequate measures to curb it.

Research methodology: A total of 370 questionnaires were administered to traders, worshippers, parents and marketers. The interview was also conducted in mosques and churches, markets and houses to collect data during and after the Covid-19 lockdown. The data were collected within a month from Tuesday 21 May 2020 to 21 June 2020.

Article History

Received on 28 April 2021

Revised on 17 May 2021

Accepted on 18 May 2021
Results: The results reveal that $67 \%$ of the respondents see commercial activities doing well before the lockdown, but only $12 \%$ during the lockdown and a further 59\% after the lockdown. The results also reveal that $56 \%$ of the respondents see educational acquisitions doing well before the lockdown, $13 \%$ during and $24 \%$ after the lockdown. The results further show that $60 \%, 10 \%$ and $53 \%$ were for before, during and after the lockdown, respectively, for religious activities.

Limitation: The data was not collected before the lockdown but only during and after. This might not give highly reliable data for one of the data was organised not at the exact time of the incidence.

Contribution: The study will help both public and private organisations appreciate the difficulties caused by the lockdown in the state so as to find alternative ways of cubing the pandemic subsequently. The study can also be replicated in some areas with similar characteristics.

Keywords: Impact, Covid-19, Lockdown, Socio-economic activities

How to cite: Muhammed, A. Y., Adenike, M., \& Salahudeen, H. (2020). The Impact of Covid-19 lockdown on socio-economic activities in Kaduna State, Nigeria. Journal of Sustainable Tourism and Entrepreneurship, 2(1), 41-51.

\section{Introduction}

The Coronavirus Infectious Disease 2019 (Covid-19) is a respiratory illness caused by a dangerous virus, with the name Severe Acute Respiratory Syndrome coronavirus 2 (SARS-CoV-2). A town called Wuhan in Hubei region of China was where the first case of Covid-19 was detected in December 2019 (Brüssow, 2020; Fauci, Lane \& Redfield, 2020; Gentile \& Abenavoli, 2020; Shang, Yang, Rao \& Rao, $\underline{2020)}$.

Covid-19 did affect not only public health but also other aspects of life such as education, commerce, sports, politics, religious affairs, humanitarian assistance and so on (Evans, 2020). According to Ayittey et al. (2020), China has an estimated loss of up to $\$ 62$ billion dollars within three months only (January to March 2020), while over $\$ 280$ billion was reported to have been lost within the same period in income 
across the world. The huge economic impact on food security, poverty, and all economic activities cannot be measured. For instance, people working in the private and informal sectors have their incomes dropped substantially. Household consumption, however, could be significantly affected, thereby causing malnutrition and all nutrition crises in many families as a result. Sexual abuse, especially on girls and even boys who do not attend schools and exposure on all social vices is on the increase. This has a long time impact, for it could be accompanied by trauma and unwanted pregnancies. Agro-allied companies, food and manufacturing companies, markets, supply chains, among others, would all be seriously disrupted and affected. Small and medium scale industries such as small hotels, restaurants, cafes, shops, manual handworks and other small businesses will face a substantial economic loss (Evans; Mustafa, 2020). According to WHO (2020), the economic loss to Covid-19 in the health care sector is immeasurable. Thousands of direct and indirect jobs in the health sector are affected. Averagely, for every additional $€ 100000$ spent on the health industry, there could be up to for jobs that will be lost. This is besides the loss of lives. Educationally speaking, about 200 countries worldwide, including Nigeria, have closed schools and the number has increased rapidly since late February (WHO, 2020). The multiplier economic impact attached to education like buying, selling, hire services and others is also lost to lockdown.

Religiously, the Universal Declaration of Human Rights (UDHR) and the International Covenant on Civil and Political Rights (ICCPR) are two organisations with the role of ensuring the security for freedom of religious belief (FoRB) under international human rights law. These two organisations played a significant role in providing freedom of religion and defining the circumstances where countries can limit such freedom in line with countries' interest in protecting public health and lives in general. Article 18(3) of the ICCPR provides that a government cannot limit the expressions of freedom of religion except if the limitation (1) is prescribed by law; (2) serves one of the following reasons, that include protecting the fundamental rights of others on health issues, the safety of lives and properties, morals among others and (3) is mandatory for achieving the listed reason. Looking at other rights that can easily be limited, freedom of religion may not be tampered with by countries when there is an emergency problem or during the war. Following the two organisations guidelines, public health may be called upon to allow a government to take actions that will deal with anything that will endanger the lives of its citizens or the life of an individual in that country (WHO, 2020). This declaration, therefore, justifies the religious lockdown in many countries, including Nigeria and Kaduna State.

For instance, there was a massive cancellation of many Roman Catholic Church activities that gather thousands of people in Italy that include the famous Ash Wednesday, especially in Rome, the capital of Italy. In Milan, worshippers were restricted from sitting or attending the church en masse, but they can visit churches individually. In some churches, they broadcast their programs via electronic or social media and even print media. Still, Milan has a large number of Jews that accommodate about 7,000 Jews, only second to a large number of Jews community in Italy after the city of Rome has suspended their services. In the same vein, there was another suspension of all activities as announced by the Vatican on 8 March. The Vatican did a live stream of Pope's general audience.

In Saudi Arabia, the country Muslims are asked to visit at least once in their lifetime if they have the means; they announced their first case of Covid-19 on 2 March 2020. However, before the announcement on 26 February, the Kingdom of Saudi Arabia had banned foreigners from travelling to the country, especially to visit the two holy Islamic cities of Makka and Medina for religious rites over the fears of aggravating the spread of Covid-19 in the Kingdom and beyond. Furthermore, on 8 March 2020 , the country had suspended the movement from and to Qatif province, where the first 11 cases of Covid-19 was reported in the country. Qatif province is a Shiitte dominated area of the country that share boundary with Iran, a country that has the largest Shi'a Muslim and has many Shi'a pilgrimage site. In fact, the whole Hajj was restricted to only about 10,000 as against approximately 3,000,000. Whether Buddhism or Hinduism, the story is the same all over the world (United States Commission on International Religious Freedom, 2020).

In light of the above, this study is aimed at analysing the impact of Covid-19 lockdown in Kaduna State on socio-economic activities with a focus on education, religious and economic/commercial sector so 
that the public can understand the difficulties caused by the lockdown and develop alternative ways of cubbing the pandemic.

\section{Literature review hypothesis development \\ 2.1. Epidemiology}

Many patients were infected with pneumonia and respiratory problems around December 2019 in the city of Wuhan, Hubei region of China. This respiratory issue resembled the SARS endemic that occurs back in the year 2003 (WMHC 2019, www.SARSReference.com in Kamps and Hoffmann, 2020). Within only one month, that is, January 2020, a new virus had emerged that seriously affect bronchoalveolar lavage fluid samples and found to be a betacoronavirus (Zhou, 2020 cited in Kamps and Hoffmann, 2020). From January 2020 to June 2020, the virus, which was renamed SARS-COV-2, has spread to all the nooks and crannies of the world, with Asia, Europe and America as the most affected regions of the world. Millions of people were tested to be infected with the virus infection, and several thousand have died of Covid-19 as of June 2020. Experts discovered that the disease is capable of causing colossal and collateral damage and a long-lasting pandemic not only where it originates but all the areas affected.

\subsection{Transmission hotspots}

Unlike some diseases that are confined to certain places, the transmission of SARS-COV-2 is surrounded by contact and closeness with infected persons. Interacting with infected persons make one vulnerable or susceptible to the infectious disease. Thus, the virus spread widely through interacting with family, friends at home, colleagues at various workplaces, hospitals where diseases are treated, vehicles through transportation, and many other places of physical contacts like field sports events and mass gatherings like the prisons.

\subsection{Homes}

The infection rate at home is not the same. It is estimated to differ within the range of between $11 \%$ 19\%. According to Bi Q 2020, Jing QL 2020, Li W (2020) in Kamps and Hoffmann, 2020). A group observed that a particular household contact and those travelling had a six to seven times higher risk of being infected than other close contacts who are not at home. The study further stated that the probability of older men being infected is the same as children (Bi Q 2020 in Kamps and Hoffmann, 2020). However, (Jing QL, 2020 cited in Kamps and Hoffmann, 2020) disagreed with the finding and observed that the possibility of infection among young men and children of less than 20 years old was only 0.26 times that among the elderly of greater or equal to 60 years old. Another study differed from the first two findings where (Li W, 2020 in Kamps and Hoffmann, 2020) discovered that the secondary attack rate in children was far below that of adults at $4 \%$ and $17.1 \%$. Additionally, the spouse infection rate was $27.8 \%$ compared to $17.3 \%$ in other adults who were not spouses.

\subsection{Workplaces}

According to (Bohmer, 2020 in Kamps and Hoffmann, 2020), SARS-CoV-2 was found to spread during workshops and meetings as early as January 2020. As time goes on, 94 out of 216 workers working in the same place were infected, given it a transmission rate of about 44\% (Park, 2020 cited in Kamps and Hoffmann, 2020). It was reported in some European countries like Germany, France, and the US met in Munich, Germany, where they held a meeting with a U-Shaped like round table and the person shook hands, take drinks four times. In the words of Hijnen (2020) in Kamps and Hoffmann, 2020) mere presence of an infected person in a workplace can be an important catalyst for spreading the deadly virus.

\subsection{Hospitals and other health care centres}

It is reported that hospitals and other health caregivers contributed a lot to the early spread of covid-19. Early transmission through this means was outside the Arabian Peninsula, which occurred in the Korean republic in 2015. Of the 186 cases reported, 164 were reported infected. In a report by Wiscon (2020) in Kamps and Hoffmann, 2020), hospitals were a favourable environment for the spread of Covid-19 and could even be the main hub of Covid-19 spread as they were rapidly populated by infected patients, facilitating transmission to health workers and uninfected patients (Nacoti, 2020 cited in Kamps and Hoffmann, 2020). For instance, within the first six weeks of the epidemic in China, about 2000 cases 
among health care workers were confirmed by nucleic acid testing, and at least 5 died $(0.3 \%)(\mathrm{Wu}$, 2020 cited in Kamps and Hoffmann, 2020). A hospital was reported to have the disease through air spread in all sections of hospitals. The virus was found on floors, computer mouse, trash cans, sickbed handrails, and detected in the air up to approximately $4 \mathrm{~m}$ from patients (Guo, 2020 cited in Kamps and Hoffmann, 2020). The virus was also isolated from toilet bowl and sink samples, suggesting that viral shedding in the stool could be a potential route of transmission (Young 2020; Tang 2020 cited in Kamps and Hoffmann, 2020).

\subsection{Long term care facilities.}

In some cases, long-term care facilities are high-risk settings for infectious respiratory diseases, including Covid-19. For instance, in one skilled nursing facility in King County, Washington, US, from the first case diagnosed with Covid-19, 167 cases of Covid-19 were detected in less than a month: Within the 167 cases, 101 were residents, 50 were health workers and 16 of them were visitors (McMichael 2020 cited in Kamps and Hoffmann, 2020). In reality, the infected persons had other chronic health conditions like hypertension, diabetes mellitus, pulmonary disease, obesity, and renal disease. However, the infected residents' average age was 83 years of age. This study revealed that as soon as a Covid-19 disease is introduced into a long term care facility, whether by a medical person or by a visitor, SARS-COV-2 has the potential of spreading rapidly and widely with a devastating end. Another long term health care facility study in Lombardy, Italy, a hot spot of the epidemic in the country that covered $96 \%$ of all long-term care facilities, revealed that $53.4 \%$ of the 3,045 residents who died between 1 February and 14 April were either detected with the virus or presented flu-like symptoms, a death rate among residents of $6.7 \%$. Among the 661 residents who were admitted in the hospital during the same period, 199 (30\%) were found positive by a PCR test. According to WHO estimates, in countries in the European Region, up to half of those who have died from Covid-19 were residents in long-term care facilities (Kamps and Hoffmann, 2020).

\subsection{Mass gatherings}

Many mass gathering events have been associated with intimidating outbreaks of the virus disease. Around 24 April 2020, a total of 5,212 coronavirus cases were related to an outbreak at the Shincheonji Church in South Korea, accounting for about $48.7 \%$ of all infections in the country. In another mass gathering event, a football match played in Milan, Italy, on 19 February 2020 was devastating and was also described as "a biological bomb". The match was attended by 40,000 spectators from Bergamo, Italy and 2,500 from Valencia, Spain and played just two days prior to the first positive case of Covid19 was confirmed in Italy. More than one-third of Valencia's team members were confirmed positive for the virus a few weeks later, along with several Valencia fans. By mid-March, there were nearly 7,000 people in Bergamo who were confirmed positive for the virus, with more than 1,000 deaths, making Bergamo the most heavily hit region during the Covid-19 outbreak in Italy. Valencia also had 2,600 cases of infection. The yearly Christian open door church gathering held between $17^{\text {th }}$ and $24^{\text {th }}$ February, 2020 in Mulhouse, France, was attended by close to 3000 people and it became the first major cluster in France with the Covid-19 problem. The cluster issue in this French region came to the limelight when the first case of a parishioner and his 18 family members were tested positive for Covid19 on 1 March 2020. The report went further to say that more than 1000 persons that attended the Mulhouse gathering were later on found to be infected with the virus in France. Arguably, a large number of people diagnosed with Covid-19 cases and deaths in France and neighbouring Switzerland, Belgium and Germany were connected to Malhouse gathering (Kamps and Hoffmann, 2020).

\subsection{Schools and school children}

The apparent role of school-aged children in SARS-COV-2 transmission is still not clear. In a small Covid-19 cluster detected in the French Alps at the end of January, one person returning from China infected eleven other people, including a nine-year-old schoolboy. The researchers, who identified this, were closely tracked and tested all contacts (Danis; 2020 in Kamps and Hoffmann, 2020).

\subsection{Review of past studies}

Buheji, Cunha, and Mavric (2020) explored the extent of the Covid-19 pandemic on the socio-economic impact on global poverty. Four continents, namely: Africa, Asia, Europe and North America, were 
chosen. The study revealed how hard it was for the poor to comply with Covid-19 protocol, such as staying at home as safety measures against the infection and containing the virus or preventing further spread. Education, economy, health, sports were the worst hit, according to the study.

Another study conducted by the United Nations High Commission on Refugees (UNHCR) (2020) in six geopolitical zones of Nigeria using survey strata on the impact of Covid-19 on economic, social, cultural, civil and political rights of Persons of Concerns (PoCs) used both quantitative and qualitative techniques with the data derived from UNHCR database to draw the sample and was analysed in line with the respective five socio-economic variables listed. The results revealed that PoCs in Nigeria was negatively impacted on the socio-economic status. The restrictions or lockdown imposed by the government at all level to curtail the spread has affected income significantly, with about $95 \%$ of PoCs being affected. There was also a high rise in food prices. PoCs were denied access to education, the market, financial services and others. In addition, PoCs are vulnerable to infection, sexual abuse, extortion, among others.

Additionally, a World Bank survey in conjunction with the National Bureau of Statistics in Nigeria on the National Longitudinal Phone Survey (Covid-19 NLPS) done continuously and in four phases with the first round from 20 April to 11 May 2020; the second round implemented between 2 June and 16 June, and the third round implemented between 2 July and 16 July, used 1,950 households drawn from the regional representative including both rural and urban areas. Findings revealed that the commercial, service and agricultural sectors were seriously affected by the spread of the virus. However, the second and third rounds in June and July showed a significant improvement in employment, especially for rural households and those in the agricultural sector. Only $34 \%$ of the PoCs have been working continuously since the breaking out of the pandemic in Nigeria, while $66 \%$ experience some time out of work. Food security was affected, with about $90 \%$ of the PoCs consumed less food. $38 \%$ of households with schoolage kids reported that their kids had not engaged in any educational pursuant.

In the same vein, the UNDP report on the socio-economic activities in Nigeria (2020) indicated the overstretched of hospitals in Nigeria due to Covid-19 infections. Oil prices have fallen by almost $60 \%$. Naira has come under severe pressure with a high depreciation rate against the dollar. There were also significant job losses. The report also revealed that the Nigerian services, trade and financial sector had suffered a severe disruption. These three sectors contribute 30\% of the GDP. The report suggested that government, non-governmental organisations, and individuals should join hand to curtail the spread of the virus to restore normalcy.

\subsection{The study area}

Kaduna State is located in Northern Nigeria. It lies between Latitudes $9^{\circ} 01^{\prime}-11^{\circ} 34^{\prime}$ North of the Equator and Longitudes $6^{\circ} 11^{\prime}-8^{\circ} 49^{\prime}$ East of the Greenwich Meridian. The state comprises 23 Local Government Areas with 255 political wards (NPC, 2006). Kaduna State shares boundary with Zamfara State, Katsina State and Kano State to the North, Niger State to the west, Federal Capital Territory and Nasarawa State to the South, Plateau and Bauchi States to the East. It is the third most populous state in Nigeria after Kano State and Lagos State and in terms of Landmass, Kaduna State ranks fourth after Niger State, Borno State and Taraba States (NPC, 2006).

A large number of the populace in the state are farmers, while others are involved in vocations such as white-collar jobs, business, craft and arts. Kaduna is a major commercial city and is second only to Kano in Northern Nigeria (KADCCIMA, 2014). Most of the industries in Kaduna State are located in Kaduna and Zaria metropolises. Certainly, the locations are influenced by government policy and probably market. Other small to medium scale industries are too numerous to list, but very important in providing portable equipment for rural dwellers (KADCCIMA, 2014). Agriculture contributes a lot to the economy of the state. Both food crops and cash crops are cultivated, which include: rice, maise, guinea corn, millet, cassava, yam, beans, groundnut, ginger and many more. Kaduna State is a metropolitan as well as a cosmopolitan industrialised state with over 80 commercial and manufacturing industries. Goods and products ranging from consumer goods like soft drinks, dairy products, groundnut oil, flour and many more are commercially produced. Other goods such as textile materials, toiletries, 
cigarettes, carpets, reinforced concrete materials are also produced in the commercial Kaduna State Agricultural Structure Survey (KASS, 2017).

The security challenge in North-Eastern Nigeria (Boko haram insurgency) has increased the influx of people into the state who migrated to seek a better place to do business, which has increased trading exponentially. There is an enabling environment for investors from parts of Nigeria and all parts of the world because the government has provided an enabling environment to investors for ease of doing business. Kaduna State has numerous tourist attractions and many comfortable Three-star hotels. There are many tourist attractions in the state, like the Matsirga Waterfalls in Kafanchan, the Kufena Hills in Zaria, the Emirs Palace in Zaria, the Fifth Chuckker in Kaduna, the Nok culture in Kwoi, the Lugard Bridge in Kaduna and many modern gardens Tourist. Kaduna Investment and Promotion Agency (KADIPA, 2017).

Kaduna State is known as the centre of learning in Nigeria because of the presence of a large number of institutions of higher learning like the famous Ahmadu Bello University, Zaria, Kaduna Polytechnic, Kaduna Nigerian College of Aviation and Technology, Zaria, Nigerian Defence Academy, Kaduna, Command and Staff College, Jaji, Nigerian Institute for Transport Technology, Zaria, National Board for Technical Education, Kaduna, Nuhu Bamalli Polytechnic, Zaria, National Teachers' Institute, Kaduna, Kaduna State University, Kaduna, National Research Institute for Chemical Technology, Zaria, Federal College of Education, Zaria, Kaduna State College of Education, Gidan waya, National Board for Arabic and Islamic Studies, Kaduna and other institutions, Barewa College, Zaria, many secondary and primary schools (KDCCIMA, 2014).

The majority of the people in the state are Muslims; however, there are a large number of Christians as evidence by the proliferation of churches in the state.

\subsection{Research hypothesis}

For the purpose of this study, this hypothesis was formulated:

Hypothesis: There is no significant impact of Covid-19 Lockdown on Socioeconomic Activities in Kaduna State.

\section{Research methodology \\ 3.1. Types of data}

Data on socio-economic activities like commercial condition before, during and after lockdown. Educational situation before, during and after lockdown. And religious activities like attending five daily prayers and church service condition before, during and after lockdown. These data were collected in markets and the ancillary places of service houses for parents and guardians of school-age children and worship places (mosques and churches) in the study area respectively.

\subsection{Sources and methods of data collection}

Primary data was collected through questionnaire administration and in-depth interview. A total of 370 questionnaires were administered to traders in their places of business after lockdown, worshippers at home during lockdown and mosques and churches after lockdown and students/parents/guardians at home during and after lockdown. The interview was conducted with many stakeholders to substantiate what is contained in the questionnaire. The data were collected within a month. Thirty-nine (39) questionnaires were not returned but were replaced.

\subsection{Research population and sampling technique}

A total of 370 respondents were derived from eight Local Government Areas (LGAs) with the highest number of Covid-19 reported cases as of June 2020. The data were collected out of 23 LGAs in the state using purposive sampling. The selected LGAs are: Kaduna North, Kaduna South, Igabi, Chikun, Zaria, Sabon-Gari, and Jema'a LGAs. The questionnaires were proportionately administered across the selected LGAs. Thus, LGAs with 370 and above reported cases of Covid-19 were administered 70 questionnaires. LGAs with 250-349 reported cases were administered 50 questionnaires. LGA with 200-249 reported cases were administered 40 questionnaires and LGA with less than 200 reported cases were administered 20 questionnaires. Therefore, 70 questionnaires were administered to Kaduna North 
and Kaduna South, 50 to Chikun, Igabi, and Zaria, 40 to Sabon Gari, and 20 to Giwa and Jema'a LGA, respectively. See figure 1 for the questionnaire proportion.

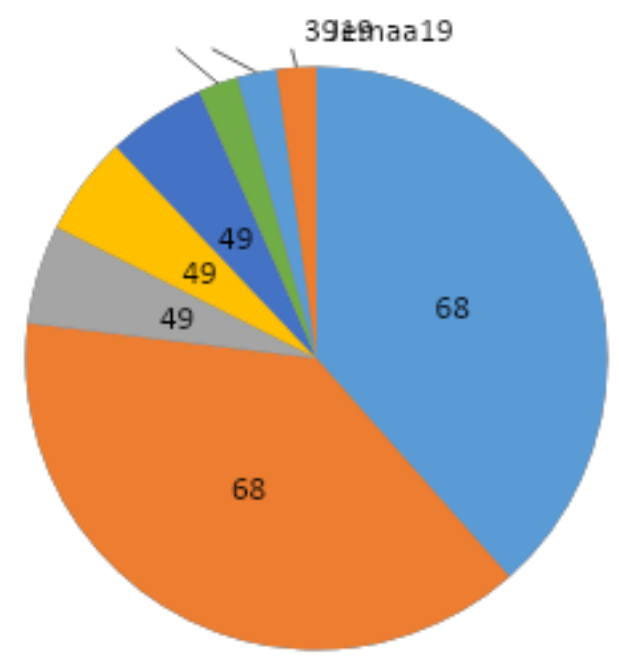

Figure 1. The proportion of leading LGAs with Covid-19 reported cases in Kaduna State

\subsection{Data Analysis}

The data were analysed using the descriptive method by employing table and percentage and inferential statistical method using Pearson's product-moment correlation.

\section{Results and discussion}

Table 1. Commercial activities before lockdown

\begin{tabular}{|c|c|c|c|c|}
\hline Rating & & Frequency & Percent & Cumulative Percent \\
\hline & Good & 248 & 67.1 & 67.1 \\
\hline & Fair & 63 & 17.0 & 84.1 \\
\hline & $\mathrm{Bad}$ & 59 & 15.9 & 100.0 \\
\hline & Total & 370 & 100.0 & \\
\hline
\end{tabular}

Source: Field Survey, 2020

From Table 1, the majority of the respondents, 248 representing $67.1 \%$, felt the commercial activities like buying and selling, lower cost of production, profit-making and others were in good condition and only 59 of the respondents representing $15.9 \%$, though it was "bad" shape. This reveals that people were not in a serious or critical condition as both the informal and informal sectors of the economy were not restricted to movement at various places of business. But despite $67.1 \%$ positive responses recorded in this important aspect of life, commercial activities, the result from the table also reveals that there is a high poverty rate in the state. One should expect a positive response to commercial activities before lockdown to reach up to $80 \%$ or even more.

Table 2. Commercial activities during lockdown

\begin{tabular}{|c|c|c|c|c|}
\hline Rating & & Frequency & Percent & Cumulative Percent \\
\hline & Good & 46 & 12.4 & 12.4 \\
\hline & Fair & 53 & 14.3 & 26.7 \\
\hline & $\mathrm{Bad}$ & 271 & 73.3 & 100.0 \\
\hline & Total & 350 & 100.0 & \\
\hline
\end{tabular}

Source: Field Survey, 2020

Table 2 shows a massive reduction in positive response as against before the lockdown. Only 46 respondents, representing $12.4 \%$, felt the commercial activities were "good". Up to 271 respondents 
representing about $73 \%$, thought that the commercial activities were in "bad" condition. Many businesses were ruined and some closed, families were struggling in many aspects. Obviously, most of the $12.4 \%$ who thought the commercial activities were "good" must be those working with the formal sector whose income was paid regularly by their organisations despite the lockdown. Certainly, this reveals that the Covid-19 lockdown has impoverished many families as many could not afford three square meals from an economy like that of Kaduna State that was struggling even before the lockdown.

Table 3. Commercial activities after lockdown

\begin{tabular}{|c|c|c|c|c|}
\hline Rating & & Frequency & Percent & Cumulative Percent \\
\hline & Good & 209 & 59.2 & 59.2 \\
\hline & Fair & 82 & 22.2 & 81.4 \\
\hline & $\mathrm{Bad}$ & 79 & 18.6 & 100.0 \\
\hline & Total & 370 & 100.0 & \\
\hline
\end{tabular}

Source: Field Survey, 2020

From Table 3, a high number of the respondents, 209, representing $60 \%$, thought that the commercial activities were in "good" condition. Only 79 respondents representing $22.5 \%$ of the respondents, felt it was in "bad" shape. These responses reveal improved commercial activities than during the lockdown as higher positive responses were recorded. It could be deduced that the positive reactions recorded here are still less than the positive responses recorded before the lockdown. This can be attributed to the failure of many traders to return to markets and their businesses as their capital was small and they have used it up to feed families during the lockdown.

Table 4. Education before lockdown

\begin{tabular}{|l|l|r|r|r|}
\hline Rating & & Frequency & Percent & \multicolumn{2}{|c|}{ Cumulative Percent } \\
\hline & Good & 207 & 55.9 & 55.9 \\
\hline & Fair & 96 & 25.9 & 81.8 \\
\hline & Bad & 67 & 18.1 & 100.0 \\
\hline & Total & $\mathbf{3 7 0}$ & $\mathbf{1 0 0 . 0}$ & \\
\hline
\end{tabular}

Source: Field Survey, 2020

From Table 4, most of the respondents, 207 representing about 60\%, felt educational activities were in a "good" state. Only 67 representing $18.8 \%$ of the respondents, thought that education was in "bad" shape. This statistic illustrates the fact that tertiary, secondary, primary, nursery and quranic (Islamic schools) were not closed then. The $18.8 \%$ negative responses recorded could be attributed to those who were critical about the falling standard of education caused by other factors not Covid-19 lockdown in the state with poor infrastructure, inadequate staff, inadequate offices, and other facilities lacking they put into consideration in their responses. In addition, $60 \%$ positive response to education is low given its importance in the scheme of things; one may expect the answer to be at least $70 \%$.

Table 5. Education during the lockdown

\begin{tabular}{|c|c|c|c|c|}
\hline Rating & & Frequency & Percent & Cumulative Percent \\
\hline & Good & 49 & 13.3 & 13.3 \\
\hline & Fair & 65 & 17.6 & 30.7 \\
\hline & $\mathrm{Bad}$ & 256 & 69.2 & 100.0 \\
\hline & Total & 370 & 100.0 & \\
\hline
\end{tabular}

Source: Field Survey, 2020

From Table 5, as expected, the majority of the respondents, 256, representing about $70 \%$, felt educational acquisition during the lockdown was in a "bad" state as all schools were closed. Only 49 representing approximately $13 \%$ of the respondents thought it was in "good" condition. It could be deduced that even the tiny per cent that felt the educational acquisition was "good" might be parents, guardians or relatives who assisted their wards/children at home with lessons. 
Table 6. Education after the lockdown

\begin{tabular}{|c|c|c|c|c|}
\hline Rating & & Frequency & Percent & Cumulative Percent \\
\hline & Good & 89 & 24.0 & 24.0 \\
\hline & Fair & 122 & 32.9 & 56.9 \\
\hline & $\mathrm{Bad}$ & 159 & 42.9 & 100.0 \\
\hline & Total & 370 & 100.0 & \\
\hline
\end{tabular}

Source: Field Survey, 2020

From Table 6, "bad" response like during the lockdown still takes centre stage as up to 159 respondents representing about $43 \%$, felt the educational acquisition was still "bad" state. On the other hand, good responses recorded 89 , representing $24 \%$. The reason for the low good response and high "bad" response rate was because although the lockdown has been suspended on 9 June 2020 in the state, but schools have yet to reopen. "fair" response increases by nearly $50 \%$ as against during the lockdown partly because people can acquire some guidance/education not necessarily in formal schools, but in informal settings as against during the lockdown when they were restricted from movement.

Table 7. Religious activities before the lockdown

\begin{tabular}{|c|c|c|c|c|}
\hline Rating & & Frequency & Per cent & Cumulative Percent \\
\hline & Good & 222 & 60.0 & 60.0 \\
\hline & Fair & 84 & 22.7 & 81.7 \\
\hline & $\mathrm{Bad}$ & 64 & 17.3 & 100.0 \\
\hline & Total & 370 & 100.0 & \\
\hline
\end{tabular}

Source: Field Survey, 2020

From Table 7, majority of the respondents 222 representing $60 \%$ felt religious activities like going to mosque (mosque) and church as was in "good" state before the lockdown. "fair" responses recorded 84 responses representing about 23\%. This reveals that freedom of religious activities was highly enjoyed and appreciated by many people because only 64 respondents representing $17 \%$ thought that it was "bad". This is in line with the provision of the Universal Declaration of Human Rights (UDHR) and the International Covenant on Civil and Political Rights (ICCPR) the two organisations responsible for protecting and ensuring the security for freedom of religion belief (FoRB) under international human rights law.

Table 8. Religious activities during the lockdown

\begin{tabular}{|c|c|c|c|c|}
\hline Rating & & Frequency & Per cent & Cumulative Percent \\
\hline & Good & 35 & 9.5 & 9.5 \\
\hline & Fair & 68 & 18.4 & 27.9 \\
\hline & $\mathrm{Bad}$ & 267 & 72.2 & 100.0 \\
\hline & Total & 370 & 100.0 & \\
\hline
\end{tabular}

Source: Field Survey, 2020

From Table 8, religious activities recorded the lowest response in the whole study, 267 representing $72 \%$. In comparison, $10 \%$ and $28 \%$ were for "good" and "fair" condition responses, respectively. This reveals that the lockdown's religious activities were greatly affected by reaching $72 \%$ "bad" responses. Mosques and churches were all closed, and only a few religious activities were conducted, and most of them were at home.

Table 9. Religious activities after the lockdown

\begin{tabular}{|l|l|r|r|r|}
\hline Rating & & Frequency & Percent & \multicolumn{2}{|c|}{ Cumulative Percent } \\
\hline & Good & 188 & 53.5 & 50.8 \\
& Fair & 88 & 23.8 & 77.2 \\
\hline & Bad & 94 & 25.0 & 100.0 \\
\hline & Total & $\mathbf{3 7 0}$ & $\mathbf{1 0 0 . 0}$ & \\
\hline
\end{tabular}


From Table 9, most of the respondents, 188 representing about 54\%, felt that religious activities were again in a "good" state. Up to 88 respondents representing approximately $24 \%$, opted for a "fair" response. This reveals that normalcy is gradually being restored as the good response for religious activities was only slightly higher before the lockdown compared to this time, after the lockdown. This further illustrates that some people were still apprehensive about going out for prayers and religious services in both mosques and churches for fear of contacting the novel virus.

\section{Hypothesis testing}

Table 10. Pearson Product Moment Correlation Coefficient on Impact of Covid -19 Lockdown on Socioeconomic Activities

\begin{tabular}{|l|r|r|r|r|r|}
\hline \multicolumn{1}{|c|}{ Variables } & \multicolumn{1}{c|}{ N } & \multicolumn{1}{c|}{ Mean } & \multicolumn{1}{c|}{ SD } & \multicolumn{1}{c|}{ r } & \multicolumn{1}{c|}{ P } \\
\hline Covid 19 Lockdown & 370 & 21.3 & 4.1 & -.671 & .0001 \\
\hline Socioeconomic Activities & 370 & 17.4 & 3.4 & & \\
\hline
\end{tabular}

Table 10 reveals that a significant inverse relationship exists between Covid-19 lockdown and socioeconomic activities (commercial activities, educational acquisition and religious activities) in Kaduna State $r=-.671$ and $p=.0001$. This is because the $p$-value of .0001 is less than the 0.05 level of significance. The correlation coefficient reveals that the higher the lockdown, the lower the socio-economic activities in Kaduna State and vice-versa. Thus, the hypothesis which states that there is no significant impact of Covid-19 Lockdown on Socioeconomic Activities in Kaduna State is hereby rejected.

\section{Limitations}

The data was not collected before the lockdown but during and after. This might not give highly reliable data. A high reliable data should have a record prior to the lockdown, although the lockdown was not anticipated.

\section{Conclusion}

This study analyses the impact of Covid-19 lockdown in Kaduna State on socio-economic activities. Socio-economic activities bordering on economy/commercial activities, education as well as religious activities were analysed. The study reveals that people were still apprehensive about attending the mosque and church service after the suspension of the lockdown-discoveries with the health services in the state, especially when the lockdown was imposed. Commercial activities were significantly affected as many marketers lost their capitals due to the lockdown, thereby making them still stay at home-additionally, commodities price increase and household income decreases. The study also found that educational activities experienced a significant negative impact. For instance, a large number of students did not learn or revise their studies, especially in formal schools.

\section{Recommendations}

1. This study reveals that Covid-19 lockdown in the state has aggravated the poor condition or poverty rate. The state's poor economy can be improved when individual, public and private sectors work together to stop the spread of Covid-19, which, if allowed to continue, might cause further state lockdown. Thus, people should live responsibly by abiding with Covid-19 protocols like washing hands, using hand sanitisers, wearing facemasks, and, of course, given social or physical distance.

2. The study reveals a serious problem with educational acquisition during the Covid-19 lockdown, the problem with education has been there, but was aggravated by the lockdown. This means that there is much to do by the Kaduna State Government in educational delivery because many people are not satisfied. Teachers in Kaduna State need to do more to regain the lost ground due to the Covid-19 lockdown. In addition, governments at all level need to provide incentives or rewards to the outstanding staff to create healthy competition among those who strive to regain the lost time caused and aggravated by the lockdown. 
3. Religious institutions are highly influential in Nigeria. Therefore, Mosque Imams and Church Pastors should make sure that their followers adhere to the Covid-19 protocols as stated in recommendation (1) above. This is one of the ways to avoid further state lockdown.

\section{References}

Ayittey, F. K., Ayittey, M. K., Chiwero, N. B., Kamasah, J. S., \& Dzuvor, C. (2020). Economic impacts of Wuhan 2019-nCoV on China and the world. Journal of Medical Virology.

Buheji, M., Cunha, K C, and Mavric, B. (2020). The extent of Covid-19 pandemic on socio-economic impact on global poverty. A global integrative multidiciplinary review. Retrieved on 4 May, 2020 from www.google.com.

Brussow, H. (2020). The Novel Coronavirus-A Snapshot of Current Knowledge. Microbial Biotechnology. https://doi.org/10.1111/17517915.13557

Evans O. (2020). Socio-economic impacts of novel coronavirus: The policy solutions. BizEcons Quarterly, 7, 3-12.

Fauci, A. S., Lane, H. C., \& Redfield, R. R. (2020). Covid-19-Navigating the Uncharted. The New England Journal of Medicine. 10.1056/NEJMe2002387

Gentile, I., \& Abenavoli, L. (2020). Covid-19: Perspectives on the Potential Novel Global Threat. Reviews on Recent Clinical Trials, 15(2), 1.

Chamber of Commerce, Industry, Mines and Agriculture (KADDCCIMA) (2014). Retrieved on 20 August, 2014 from http://www.kadccima.org.ng

Kaduna Investment and Promotion Agency [KADIPA] (2017). Investment and Ease of Doing Business Report.

Kaduna State Agricultural Structure Survey [KASS] (2017). 2016 GDP Kaduna State Report.kdbs.ng

Kamps, B.S. and Hoffmann, C. (2020). COVID Referencewww.CovidReference.comFourth Edition Uploaded on 9 June 2020.

Mustafa, N. (2020). Impact of the 2019-20 Coronavirus Pandemic on Education. International Journal of Health Preferences Research. Retrieved 15-06-2020.

National Population Census (2006). Comprehensive Result of 2006 Population census. Retrieved on 15 November, 2013, from www.google.com

Shang, W., Yang, Y., Rao, Y., \& Rao, X. (2020). The outbreak of SARS-CoV2 pneumonia calls for viral vaccines. npj Vaccines, 5(1), 1-3.

Socio-economic Impact and Assessment of Covid-19 Pandemic among Persons of Concern in Nigeria. (July, 2020). UNHCR. Retrieved on 25 August, 2020.

UNDP (2020). The Impact of the Covid-19 Pandemic in Nigeria. A Socio-Economic Analysis. Retrieved on 24 March, 2020.

World Bank and National Bureau of Statistics (2020). National Longitudinal Phone Survey on Covid19 (Covid-19 NLPS). Retrieved on 10 August, 2020 from http://www.nbs.org.ng

World Health Organization. Infection prevention and control during health care when Covid-19 is suspected https://www.who.int/publications-detail/infection-prevention-andcontrol-during-health-care-when-novel-coronavirus-(ncov)infection-is-suspected-20200125 